\title{
A molecular marker distinguishes the subspecies Melipona quadrifasciata quadrifasciata and Melipona quadrifasciata anthidioides (Hymenoptera: Apidae, Meliponinae)
}

\author{
Ana M. Waldschmidt ${ }^{1}$, Everaldo G. de Barros $^{2}$ and Lucio A.O. Campos ${ }^{2}$
}

\begin{abstract}
The stingless bee species Melipona quadrifasciata includes two subspecies, Melipona quadrifasciata anthidioids and Melipona quadrifasciata quadrifasciata. The morphological difference between the two subspecies is the presence of three to five continuous yellow stripes on the terga on the 3rd to 6th segments in workers and males of M. q. quadrifasciata, and two to five interrupted bands in M. q. anthidioides. We identified a DNA marker which is present in M. q. quadrifasciata and absent in M. q. anthidioides. Only one among the M. q. quadrifasciata colonies did not present the marker. It was also absent in bees collected in northern Minas Gerais State (Brazil), despite their morphological resemblance to M. q. quadrifasciata. The marker can be used for studying the genetic structure of the hybridization zone formed by the intercrossing of the two subspecies.
\end{abstract}

\section{INTRODUCTION}

The genus Melipona (Hymenoptera: Apidae; Meliponinae), represented by more than 40 known species, is limited to the neotropical regions of South and Central America, including the Caribean Islands (Camargo, 1979; Michener, 1979, 1990).

In Brazil, Melipona quadrifasciata Lep., known as mandaçaia, may be found along the coast side, from the State of Paraíba to the State of Rio Grande do Sul (Moure and Kerr, 1950). It has been subdivided into two subspecies: Melipona quadrifasciata anthidioides Lep. and Melipona quadrifasciata quadrifasciata Lep., which differ by the presence of three to five continuous yellow stripes on the terga on the 3rd to 6th segments in workers and males of M. q. quadrifasciata, and of two to five interrupted bands in worker and males of M. q. anthidioides (Schwarz, 1948).

RAPD (random amplified polymorphic DNA) is a simple and straightforward PCR-based technique which does not require previous knowledge about the sequence being amplified. These markers are extremely useful for genetic and taxonomical population studies (Suazo et al., 1998). These authors detected specific RAPD markers which were able to distinguish races of African and European Apis mellifera.

These RAPD markers could also be used for macrogeographic studies of the structure of hybrid zones, where populations differing by a few, or several characteristics, intercross (Futuyma, 1993). These zones can provide im- portant evolutionary information concerning the degree of genetic introgression, the way barriers for genetic exchange work, and also the genetic nature and ecological differences between species (Harrison, 1990). The availability of specific RAPD markers greatly facilitated the study of the hybrid zone formed by two ant species, Solenopsis invicta and $S$. richteri (Shoemaker et al., 1994).

A hybridization zone was detected in some regions of the State of São Paulo and in southern Minas Gerais involving intercrossing between individuals from subspecies M. q. quadrifasciata and M. q. anthidioides. In these areas hybrid individuals with intermediate abdominal yellow stripe patterns can be found (Moure and Kerr, 1950).

The main goal of this work was to identify RAPD markers that could distinguish between the subspecies $M$. $q$. anthidioides and M. q. quadrifasciata at the molecular level. The marker(s) could then be used for studies of the hybrid zone formed by the intercrossing of the two subspecies.

\section{MATERIAL AND METHODS}

Genetic material

Fifty-eight colonies of $M$. quadrifasciata from different states of Brazil were used, 13 from Minas Gerais, 15 from Espírito Santo, 15 from Paraná, 14 from Santa Catarina, and seven from São Paulo. All colonies from Santa Catarina and two from Paraná belonged to the subspecies M. q. quadrifasciata. Two colonies from Paraná presented 
a hybrid abdominal pattern. Five of the colonies collected in Minas Gerais presented a morphological pattern similar to that of M. q. quadrifasciata. All other colonies belonged to the subspecies $M$. q. anthidioides. Ten workers were collected from each colony for DNA extraction.

\section{DNA extraction}

The protocol described by Waldschmidt et al. (1997) was used for DNA extraction.

Prior to amplification, the DNA samples were grouped in bulks each containing equal amounts of DNA extracted from the 10 workers from each colony.

\section{DNA amplification}

DNA was PCR amplified according to Williams et al. (1990). The reaction mixture $(25 \mu \mathrm{l})$ contained $25 \mathrm{ng}$ of genomic DNA, $3.5 \mathrm{mM} \mathrm{MgCl}_{2}, 10 \mathrm{mM}$ Tris-HCl, $\mathrm{pH} 8.3$, $50 \mathrm{mM} \mathrm{KCl}, 0.1 \mathrm{mM}$ of each dNTP (dATP, dTTP, dCTP, dGTP), $0.4 \mu \mathrm{M}$ of a decamer primer (Operon Technologies, Alameda, CA, USA), and 1 unit of Taq DNA polymerase.

Amplification products were analyzed on $1.2 \%$ agarose gels containing $10 \mu \mathrm{g} / \mathrm{ml}$ ethidium bromide, imersed in TBE buffer (90 mM Tris-borate, 1 mM EDTA, $\mathrm{pH}$ 8.0). DNA bands were visualized under UV light and photographed with type 667 polaroid film.

\section{RESULTS AND DISCUSSION}

Subspecies M. q. quadrifasciata can be found in Brazil in the States of Paraná and Santa Catarina, and in the southern part of the State of São Paulo, particularly in regions with high altitudes and low temperatures (Melo and Campos, 1987). Subspecies M. q. anthidioides is found in regions with high temperatures such as the northern part of the States of Minas Gerais and Rio de Janeiro. In Minas Gerais, the occurrence of M. q. anthidioides is more frequent. However, individuals with an abdominal pattern identical to that of $M$. q. quadrifasciata were found in the northern part of the state in warm regions with altitudes ranging from 500 to $700 \mathrm{~m}$ (Melo and Campos, 1987).

One hundred and fifty different primers were used to amplify the DNA extracted from the Melipona workers. Primer OPE-O7 (5' AGATGCAGCC 3') led to the amplification of a DNA band $(\sim 750 \mathrm{~kb})$ which was present in all individuals from subspecies M. q. quadrifasciata and absent in individuals from subspecies $M$. q. anthidioides and in those collected in northern Minas Gerais, which nevertheless present an abdominal pattern identical to that of M. q. quadrifasciata (Figure 1).

Only one out of the 15 colonies from the State of Santa Catarina did not present that marker band, possibly due to mutation. The two hybrid colonies collected in Paraná presented the DNA band which is well in accordance with their hybrid origin (Figure 1, lanes 5 and 6).
When the DNA samples from the twenty individuals composing the two bulks corresponding to these hybrid colonies were individually amplified, some of them bore the marker and others did not (Figure 2), confirming the hybrid condition of the colonies.

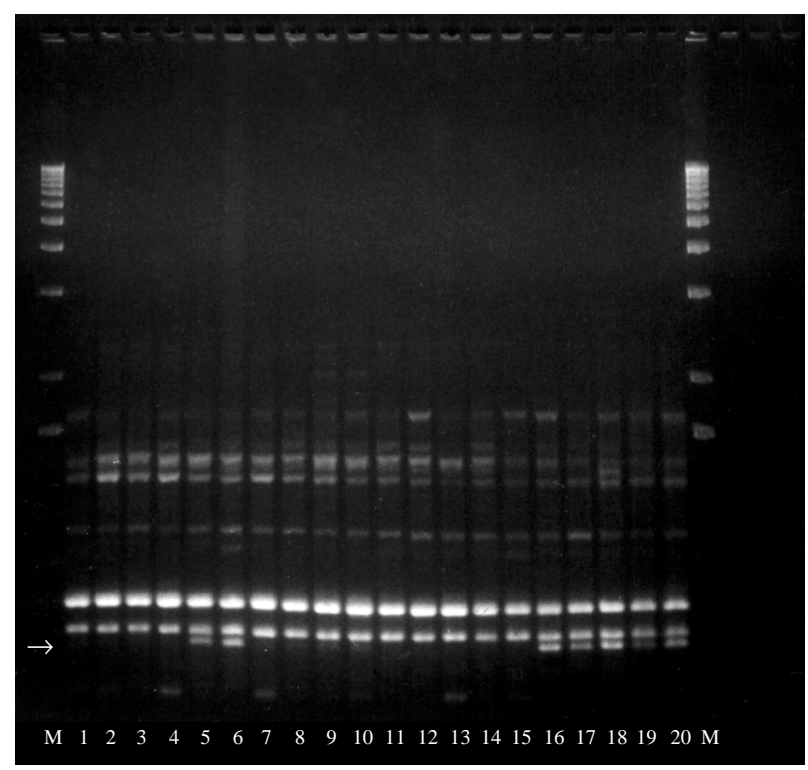

Figure 1 - Electrophoretic analyses of DNA amplification products from M. quadrifasciata colonies with primer OPE-07. Lanes are as follows: M, 1-kb DNA ladder size markers; 1-4, colonies collected in Minas Gerais; 511, colonies collected in Paraná; 12-15, colonies collected in Espírito Santo; 16-20, colonies collected in Santa Catarina. The arrow indicates a DNA band present in M. q. quadrifasciata and absent in M. q. anthidioides.

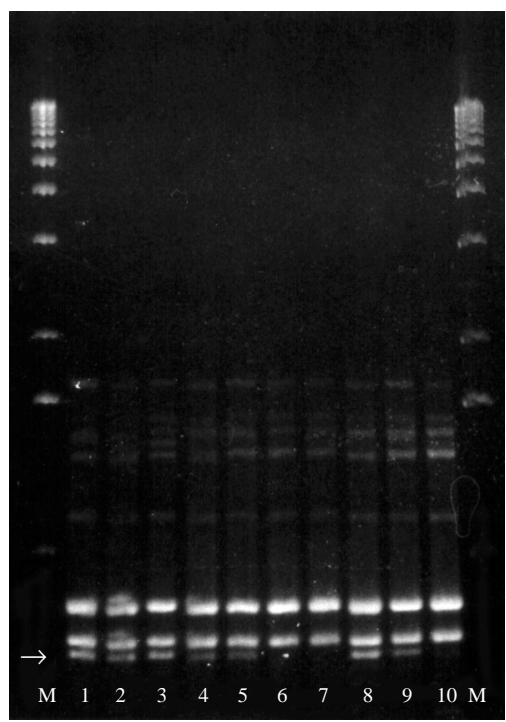

Figure 2 - Electrophoretic patterns of genomic DNA extracted from individuals from one hybrid colony of $M$. quadrifasciata, amplified with primer OPE-07. Lanes are as follows: M, 1-kb DNA ladder size markers; 1-10, different individuals from the hybrid colony. The arrow indicates a band present only in individuals from the subspecies $M$. q. quadrifasciata. 
The marker was not present in individuals from northern Minas Gerais. Although the workers from these colonies were morphologically identical to $M$. q. quadrifasciata, they live in areas with high temperatures, where individuals from the subspecies $M$. q. anthidioides are prevalent. The absence of the marker in the individuals collected in northern Minas Gerais State may be the result of a selective process linked or not (neutral marker) to genes with a noticeable phenotypic effect. The marker may have been acquired or lost due to a bottleneck effect, genetic drift or to mutations in a scenario of limited genetic flow.

The presence or absence of the marker band cannot, however, be used as the only criterion to classify an individual as being from one subspecies or the other. The marker identified in this work, in association with morphometric data, could be used to study the genetic structure of hybrids in zones such as those occurring in the State of Minas Gerais.

\section{ACKNOWLEDGMENTS}

The authors are grateful to Dr. Jorge Abdala Dergam dos Santos for his valuable suggestions during the writing of this manuscript and to Sebastião Gonzaga, Davi Said Aidar, and Yasmine Antoniolli for providing the Melipona quadrifasciata samples.

\section{RESUMO}

A espécie de abelha sem ferrão Melipona quadrifasciata apresenta duas subespécies, Melipona quadrifasciata quadrifasciata Lep. e Melipona quadrifasciata anthidioides Lep. A diferença morfológica entre as duas subespécies é a presença de três a cinco bandas tergais amarelas do $3^{\circ}$ ao $6^{\circ}$ segmentos em operárias e machos de M. q. quadrifasciata e duas a cinco bandas interrompidas em M.q. anthidioides. Nós identificamos um marcador de DNA que está presente em M. q. quadrifasciata e ausente em M. q. anthidioides. Este marcador está ausente em abelhas coletadas no norte do Estado de Minas Gerais (Brasil), embora esses indivíduos apresentem morfologia similar à de $M$. q. quadrifasciata. Este marcador poderá ser utilizado em estudos da zona de hibridação entre as subespécies.

\section{REFERENCES}

Camargo, C.A. (1979). Sex determination in bees. XI. Production of diploid males and sex determination in Melipona quadrifasciata. J. Apic. Res. 18: 77-84.

Futuyma, D.J. (1993). Biologia Evolutiva. 2nd edn. Sociedade Brasileira de Genética/CNPq, Ribeirão Preto pp. 646.

Harrison, R.G. (1990). Hybrid zones: windows on evolutionary processes. Evol. Biol. 7: 129-156.

Melo, G.A.R. and Campos, L.A.O. (1987). Variações dos padrões de faixas nas populações de Melipona quadrifasciata Lepeletier, 1936 no Estado de Minas Gerais (Hymenoptera, Apidae, Meliponinae). XIV Congresso Brasileiro de Zoologia, 1 a 6 de Fevereiro, Juiz de Fora, MG.

Michener, C.D. (1979). Biogeography of the bees. Ann. MO. Bot. Gard. 66: 277-347.

Michener, C.D. (1990). Classification of the Apidae (Hymenoptera). Univ. Kans. Sci. Bull. 54: 75-164.

Moure, J.S. and Kerr, W.E. (1950). Sugestões para as modificações da sistemática do gênero Melipona (Hymenoptera, Apoidea). Dusenia 12. 105-129.

Schwarz, H. (1948). Stingless Bees (Meliponidae) of the Western Hemisphere. Bulletin of the American Museum of Natural History, New York, pp. 167.

Shoemaker, D.D., Costa, J.T. and Ross, K.G. (1994). Estimates of heterozygosity in two social insects using a large number of electrophoretic markers. Heredity 69: 573-582.

Suazo, A., McTiernan, R. and Hall, H.G. (1998). Differences between African and European honey bees (Apis mellifera $\mathrm{L}$.) in random amplified polymorphic DNA (RAPD). J. Hered. 89: 32-36.

Waldschmidt, A.M., Salomão, T.M.F., Barros, E.G. and Campos, L.A.O. (1997). Extraction of genomic DNA from Melipona quadrifasciata (Hymenoptera: Apidae, Meliponinae). Braz. J. Genet. 20: 421-423.

Williams, J.G.K., Kubelik, A.R. and Livar, K.J. (1990). DNA polymorphisms amplified by arbitrary primers are useful as genetic markers. Nucleic Acids Res. 18: 6531-6535.

(Received October 13, 1999) 
